\title{
British cancer fund to double its expenditure on research
}

\section{London}

WITH a 25 per cent increase in income last year, the UK Imperial Cancer Rescarch Fund (ICRF) is in an expansionary mood. It plans to spend more than $£ 500$ million in the next ten years, by which time annual expenditure should have more than doubled. The fund is "bucking the trend" of UK research, says its director of research, Sir Walter Bodmer.

One almost immediate plan, for which a quarter of the fund's $£ 32$ million income last year was set aside, is to convert more of the administrative offices in the Lincoln's Inn Fields building in central London into laboratories. Protein structure and pharmacology research are likely to be the beneficiaries. But overall the balance of spending in the next decade will shift more in the direction of applied research as opportunities to move from the laboratory into clinical research are exploited.

While researchers are voting with their feet in response to the declining standard of facilities and uncompetitive salaries in government-financed biomedical institutes and university departments, ICRF has no such problem, says Bodmer. ICRF cannot, of course, compete with the six-figure salaries with which US biotechnology companies lure the occasional scientist (Robert Kamen of Genetics Institute was an ICRF casualty of that type) but can afford the kind of salary and facilities to retain senior staff, claims Bodmer. This year's departure of three such staff (to start a Ludwig Institute, to a chair at the University of Oxford and to direct the Beatson Institute) is for the 'right' reasons, he says.

The ability of ICRF to maintain its protected position, let alone to expand as planned, depends on its success in persuading the public to donate money to cancer research. Legacy income is the most important single source and rose sharply last year, contributing $£ 19.2 \mathrm{mil}$ lion towards the total of $£ 32.5$ million. But hopes of a sustained increase in income are largely pinned on a growing chain of shops around the country. These are predicted to bring in $£ 14$ million ten years hence. There is also some thought of reducing the $£ 50$ million or so accumulated capital fund that ICRF holds.
Peter Newmark

\section{Radioactive release detected in Germany from Soviet source?}

\section{Munich}

Higher levels of atmospheric radioactivity measured across Europe in the first half of March were most likely the result of a leak from a nuclear reactor in the Soviet Union. This suspicion, reported last week by the West German Institute for Atmospheric Research (IAR), has led the West German government to ask the Soviets for an explanation.

The Soviet Union has filed no report of an accident with the International Atomic Energy Agency (IAEA) in Vienna. But as the amount of radioactivity measured was so small, it would not bc required to report it, said an IAEA spokesman.

Traces of radioactive iodine-131 and xenon-133 were first recorded in Finland and Sweden between 2 and 9 March. At the time, they were attributed to a nuclear test reportedly carried out by the Soviet Union on 26 February. But researchers at the IAR, where the increase in radioactivity was observed between 9 and 14 March, consider this implausible as xenon-133 has a half-life of just nine hours. The ratio of isotopes also rules out accidental release from a medical institution.
Based on the radioactivity levels measured in Germany (37 microbecquerel per $\mathrm{m}^{3}$ of air), the release may have amounted to only 1-10 curies, an amount "within normal permissible limits" for a nuclear reactor, according to an IAEA spokesman. (The accident at Chernobyl released 20 megacuries.)

One explanation for the release may have been a cracked fuel-rod canister which released these isotopes "up the stack" through the cooling system, hardly an uncommon occurrence, said the IAEA spokesman. Steven Dickman

Vera Rich adds: The Soviet Foreign Press spokesman, Gennadii Gerasimov, the minister of nuclear power, Nikolai Lukonin, and the assistant chairman of the state committee for hydrometcorology and environmental protection. Valentin Sokolovskii, have all denied that there has been any leak of radiation from Soviet sources. The Soviet radioactivity monitoring network is working well, Gerasimov said at one of his regular press briefings on 14 April, and if there has been some sort of increase in radioactivity levels in the West, it is not of Soviet origin.

\section{Conservation treatment for breast cancer}

\section{London}

THE first controlled trial of a new breastconserving treatment for breast cancer has shown that it is as effective as mastectomy. On the basis of the trial, sponsored by the Imperial Cancer Research Fund at Guy's Hospital, London, the treatment will now be that of choice in Britain, according to Dr Ian Fentiman, deputy-director of the fund.

The therapy entails the removal of the tissues of the lump in the breast and of the lymph glands under the corresponding armpit. Radioactive iridium needles are inserted for 48 hours, delivering a dose of 20 gray, with external radiotherapy as a backup.

The trial involved 800 women, half of them mastectomized controls, over a period of five years. The subjects included 200 women treated at Guy's Hospital and an equal number in Belgium and the Netherlands. The results of the study have not yet been published, but it is reckoned to be significant because the rate of cancer recurrence is found to be the same in the subject and the control groups-roughly one per cent a year.

Fentiman says that the new treatment is applicable to patients with tumours up to $4-\mathrm{cm}$ diameter. or to about 80 per cent of women with breast cancer in Britain, and that the cosmetic result has been excellent.

The death-rate from breast cancer in Britain is less than that in the United States, where pressure for conservation as an alternative to mastectomy has been mounting. Dr Samuel Hellman, physician-in-chief at Memorial Sloan Kettering Cancer Center in New York, the pioneer of the use of iridium implants, says that the new study should help to convince people that conservation techniques can be as effective as others. Kathy Johnston

\section{Italy to map the} human genome?

\section{Milan}

Italy is planning to enter the race to map the human genome, chiefly because the National Research Council (CNR) believes it has a lot to offer. CNR president Professor Luigi Rossi Bernardini, announcing the decision, said that the council's mind had been made up as the result of a large meeting held in Rome under the chairmanship of Renato Dulbecco of the Salk Institute. The plan is to set up a new institute in Rome.

Paola de Paoli 